\title{
Admission vitamin D status is associated with discharge destination in critically ill surgical patients
}

Karolina Brook ${ }^{1}$, Carlos A. Camargo ${ }^{2,3,4}$, Kenneth B. Christopher ${ }^{3,5}$ and Sadeq A. Quraishi ${ }^{1,6^{*}}$

\begin{abstract}
Background: Discharge destination after critical illness is increasingly recognized as a valuable patient-centered outcome. Recently, vitamin D status has been shown to be associated with important outcomes such as length of stay (LOS) and mortality in intensive care unit (ICU) patients. Our goal was to investigate whether vitamin D status on ICU admission is associated with discharge destination.
\end{abstract}

Methods: We performed a retrospective analysis from an ongoing prospective cohort study of vitamin D status in critical illness. Patients were recruited from two surgical ICUs at a single teaching hospital in Boston, Massachusetts. All patients had 25-hydroxyvitamin D (25OHD) levels measured within $24 \mathrm{~h}$ of ICU admission. Discharge destination was dichotomized as non-home or home. Locally weighted scatterplot smoothing (LOWESS) was used to graph the relationship between $25 \mathrm{OHD}$ levels and discharge destination. To investigate the association between $25 \mathrm{OHD}$ level and discharge destination, we performed logistic regression analyses, controlling for age, sex, race, body mass index, socioeconomic status, acute physiology and chronic health evaluation II score, need for emergent vs. non-emergent surgery, vitamin D supplementation status, and hospital LOS.

Results: 300 patients comprised the analytic cohort. Mean 25OHD level was 19 (standard deviation 8) ng/mL and $41 \%$ of patients had a non-home discharge destination. LOWESS analysis demonstrated a near-inverse linear relationship between vitamin D status and non-home discharge destination to $250 \mathrm{HD}$ levels around $10 \mathrm{ng} / \mathrm{mL}$, with rapid flattening of the curve between levels of 10 and $20 \mathrm{ng} / \mathrm{mL}$. Overall, $250 \mathrm{HD}$ level at the outset of critical illness was inversely associated with non-home discharge destination (adjusted OR, 0.88; $95 \% \mathrm{Cl} 0.82-0.95$ ). When vitamin D status was dichotomized, patients with $250 \mathrm{HD}$ levels $<20 \mathrm{ng} / \mathrm{mL}$ had an almost 3-fold risk of a non-home discharge destination (adjusted OR, $2.74 ; 95 \% \mathrm{Cl} 1.23-6.14$ ) compared to patients with $25 \mathrm{OHD}$ levels $\geq 20 \mathrm{ng} / \mathrm{mL}$.

Conclusions: Our results suggest that vitamin D status may be a modifiable risk factor for non-home discharge destination in surgical ICU patients. Future randomized, controlled trials are needed to determine whether vitamin D supplementation in surgical ICU patients can improve clinical outcomes such as the successful rate of discharge to home after critical illness

Keywords: Vitamin D, 25-hydroxyvitamin D, Critical illness, Discharge destination, Patient-centered outcome

\section{Background}

Advances in acute care medicine have resulted in declining mortality rates after critical illness [1-4].

\footnotetext{
*Correspondence: squraishi@mgh.harvard.edu

${ }^{1}$ Department of Anesthesia, Critical Care, and Pain Medicine,

Massachusetts General Hospital, Harvard Medical School, 55 Fruit Street,

GRJ 402, Boston, MA 02114, USA

Full list of author information is available at the end of the article
}

Nonetheless, survival, while evidently a positive outcome, does not truly reflect the health condition of a patient upon discharge from the intensive care unit (ICU). Among survivors, $5-10 \%$ of ICU patients transition to chronic critical illness, with estimates of between 100,000 and 250,000 such patients in the United States at any given point in time [5-8]. These chronically critically ill patients continue to depend on myriad intensive care 
resources outside of the acute care setting [7-9]. As such, within the context of a healthcare system gravitating towards patient-centered outcomes, the concept of disability-free survival is gaining popularity [10]. In hospitalized patients, discharge destination is a potential early indicator of disability-free survival [11-13], and the ability to predict or identify modifiable risk factors for discharge destination may improve patient-centered health outcomes.

Discharge destination is known to be affected by a variety of factors, which not only arise during the course of hospitalization, but may also be influenced by patientrelated factors that pre-date hospital admission. In particular, socioeconomic factors, such as insurance coverage [14], the level of support at home, and baseline functional status [15], have been shown to influence discharge destination. Additional factors, including older age, use of mechanical ventilation or the need for tracheotomy (in the setting of chronic respiratory failure), the presence of severe pressure ulcers, declines in cognitive function, and metabolic or nutritional derangements (e.g., hypoalbuminemia) may influence discharge destination after ICU admission [16-18]. Notably, while many of these identified risk factors are potentially modifiable, easily and/or rapidly correcting them can be a challenge in the clinical setting.

Although vitamin D is typically recognized for its role in promoting optimal musculoskeletal health $[19,20]$, emerging data suggests that vitamin D status, as determined by measuring its most widely accepted proxy, circulating 25-hydroxyvitamin D (25OHD) [21], may also influence various ICU-related outcomes, including length of stay (LOS), readmission, overall costs, and mortality [22-24]. Moreover, low vitamin D status has an estimated prevalence of $40-80 \%$ among critically ill patients [25-29] and can be rapidly corrected [24, $30,31]$. And while 25OHD levels may influence several provider-centered health outcomes, its role in patientcentered outcomes among survivors of critical illness is unclear. Therefore, the goal of our study was to investigate whether vitamin D status on admission to the ICU is associated with discharge destination in critically ill surgical patients.

\section{Methods}

We performed a retrospective analysis of the data from an ongoing prospective cohort study designed to assess vitamin D status in critically ill patients. A subset of these patients was previously described in studies that investigated the association of vitamin $\mathrm{D}$ status with duration of mechanical ventilation and 90-day mortality in ICU patients [22, 32]. For the present study, subjects were recruited from two, 18-bed surgical ICUs at the
Massachusetts General Hospital (MGH), in Boston, USA. Both ICUs received admissions from all surgical services except for Cardiac Surgery. All subjects were enrolled between 06/01/2012 and 05/30/2015. MGH is a 1052bed, teaching hospital and a level-one trauma center, which serves a diverse population in and around Eastern Massachusetts. The Partners Human Research Committee (local Institutional Review Board) approved the study protocol.

\section{Inclusion and exclusion criteria}

All adult males and females, $\geq 18$ years of age, and who were expected to require at least $48 \mathrm{~h}$ of critical care (as determined by the treating ICU team), were deemed eligible to participate. Informed consent was obtained either directly from subjects or appropriate healthcare surrogates. Subjects were only included in the study if blood samples to assess vitamin D status could be obtained within $24 \mathrm{~h}$ of admission to the ICU. Exclusion criteria included a known history of anemia at the time of ICU admission (defined as hematocrit $<25 \%$ ), pregnancy or immediate post-partum status, and history of vitamin D supplementation $\geq 4000 \mathrm{IU} /$ day. To minimize confounding from either partially treated, new-onset illness, or chronic illnesses, subjects were also excluded if they were transferred from another ICU or had been in an ICU within year of the most current admission. Patients expected to transition to "comfort only measures" were also excluded.

\section{Blood sample processing and biomarker assays}

Following informed consent, fresh blood was acquired from an indwelling vascular catheter and was collected directly into an ethylenediaminetetraacetic acid-containing tube (lavender top). The sample was immediately stored on ice and then centrifuged within $30 \mathrm{~min}$ to separate out plasma. All samples were centrifuged at $2,300 \mathrm{rpm}$ for $15 \mathrm{~min}$ at a temperature of $4{ }^{\circ} \mathrm{C}$. The separated plasma was immediately transferred to polypropylene tubes and stored at $-80{ }^{\circ} \mathrm{C}$ until biomarker testing was ready to be initiated. Assays were performed at the Harvard Medical School Clinical and Translational Science Award core laboratory at MGH. Plasma 25OHD (combined $D_{2}$ and $D_{3}$ ) levels were measured by enzymelinked immunoabsorbent assay (ELISA), using commercially available kits (Abbott Laboratories, Abbott Park, IL, USA). Intra- and inter-assay coefficients of variation were both $<10 \%$.

\section{Demographic and clinical data collection}

The MGH electronic medical records system was used to obtain baseline information related to the following: age, sex, race, body mass index (BMI), socioeconomic status 
(SES), acute physiology and chronic health evaluation (APACHE) II score, type of surgical patient, vitamin D supplementation status, hospital LOS, and discharge destination. We estimated SES by abstracting the residential zip code from each medical record and cross-referencing it with the US Census Bureau per capita income data [33] specific to each locality. Zip codes in the top third of the per capita income rankings for Massachusetts were considered high SES, middle third were considered moderate SES, and those in the bottom third were considered low SES. Sex, race, type of surgical patient, and in-hospital vitamin D supplementation status were dichotomized as female vs. male, non-white vs. white, emergent vs. non-emergent, and $\leq 1000$ IU vs. $>1000$ to $<4000$ IU per day throughout the hospitalization, respectively. Discharge destination was also dichotomized as non-home vs. home. A non-home discharge included all in-hospital deaths, transfers to another healthcare facility for patients who lived at home before ICU admission, and/ or transition to a higher level of care compared to baseline (e.g., nursing home resident who was discharged to an acute rehabilitation hospital after ICU admission and acute care on the general wards at MGH). A home discharge included all patients who returned home (with or without home health services) or returned to the same level of care as baseline (e.g., nursing home resident who was discharged back to his/her nursing home after ICU admission and acute care on the general wards at MGH). All other variables were considered as continuous data.

\section{Locally weighted scatterplot smoothing analysis}

Locally weighted scatter plot smoothing (LOWESS) was used to graphically represent the relationship between 25OHD levels and the risk of non-home discharge. LOWESS curves are a form of nonparametric regression, which summarize a relationship between two variables in a fashion that initially relies on limited assumptions about the form or strength of the relationship [34]. The rationale and methods underlying the use of LOWESS for depicting the local relationship between measurements of interest across parts of their ranges have previously been described [35].

\section{Statistical analysis}

Descriptive statistics were calculated for subjects with plasma $25 \mathrm{OHD}$ levels $<20 \mathrm{ng} / \mathrm{mL}$ vs. those with levels $\geq 20 \mathrm{ng} / \mathrm{mL}$. Continuous data were reported as means with standard deviations (SDs) or medians with interquartile ranges (IQRs). Comparison of characteristics was performed using $t$ test and Mann-Whitney analyses for normally distributed variables and nonparametric variables, respectively. Categorical values were expressed as proportions and compared using Chi-squared tests.
Since we considered discharge destination as a dichotomous variable, logistic regression analysis was used to model the relationship between plasma 25OHD levels and discharge destination, while controlling for biologically plausible covariates. In this approach, we controlled for: (1) age; (2) sex; (3) race; (4) BMI; (5) SES; (6) type of surgical patient; (7) APACHE II score; (8) hospital LOS; and (9) vitamin D supplementation. We then repeated the analysis with $25 \mathrm{OHD}$ levels dichotomized as $<20$ vs. $\geq 20 \mathrm{ng} / \mathrm{mL}$. This threshold was selected based on existing conservative guidelines regarding optimal vitamin $\mathrm{D}$ status [36] and observed relationship between 25OHD levels and discharge destination on the LOWESS curve. Results are reported as odds ratios (ORs) with $95 \%$ confidence intervals (CIs).

We performed an a priori sample size calculation using the previously described biologically plausible model for the association between plasma 25OHD levels and discharge destination. Based on previous studies performed by our group and others [37-39] on discharge destination, we assumed a $40 \%$ discharge to home rate in patients with plasma $25 \mathrm{OHD}$ levels $\geq 20 \mathrm{ng} / \mathrm{mL}$ and a $20 \%$ discharge to home rate in patients with levels $<20 \mathrm{ng} / \mathrm{mL}$. To detect this difference in discharge rate between groups with a power of 0.8 and with alpha set at 0.05 , a minimum sample size of 82 patients in each group would be required for the present study. All analyses were performed in STATA 13.0 (StataCorp LP, College Station, TX). A two-tailed $P<0.05$, or $95 \%$ CI that did not span 1 , was considered statistically significant.

\section{Results}

A total of 300 patients comprised the final analytic cohort (Table 1). The mean age was 66 (SD 16) years and most subjects were male ( $58 \%$ ) as well as white $(90 \%)$. Overall, mean BMI was 29 (SD 7) kg/m². Approximately 26, 40, and $35 \%$ of patients were from low, moderate, and high SES neighborhoods, respectively, while $14 \%$ of patients had emergency surgery. The mean APACHE II score was 17 (SD 9), median hospital LOS was 9 (IQR 6-14) days, and mean 25OHD level was 19 (SD 8) $\mathrm{ng} / \mathrm{mL}$. The overall in-hospital mortality rate was 16 and $41 \%$ of patients had a non-home discharge destination. Among patients who survived to hospital discharge, the non-home destination rate was $30 \%$.

LOWESS curve analysis (Fig. 1) demonstrated a nearinverse linear relationship between vitamin D status and the risk of non-home discharge destination up to $25 \mathrm{OHD}$ levels of around $10 \mathrm{ng} / \mathrm{mL}$. Between 25OHD levels of 10 and $20 \mathrm{ng} / \mathrm{mL}$, there was significant flattening of the curve. Beyond 25OHD levels of $20 \mathrm{ng} / \mathrm{mL}$, the risk curve continued to flatten incrementally. Logistic regression analysis (Table 2), while controlling for biologically 
Table 1 Demographic factors, baseline information, and clinical outcomes in surgical intensive care unit patients according to vitamin $D$ status at initiation of care $(n=300)$

\begin{tabular}{|c|c|c|c|}
\hline Characteristic & $\begin{array}{l}25(\mathrm{OH}) \mathrm{D}<20 \\
\mathrm{ng} / \mathrm{mL} \\
(n=186)\end{array}$ & $\begin{array}{l}25(\mathrm{OH}) \geq 20 \\
\mathrm{ng} / \mathrm{mL} \\
(n=114)\end{array}$ & $P$ value \\
\hline Age (years) & 64 (SD 16) & 69 (SD 15) & $<0.01$ \\
\hline $\operatorname{Sex}(\%)$ & & & 0.67 \\
\hline Female & 41 & 44 & \\
\hline Male & 59 & 56 & \\
\hline Race (\%) & & & 0.14 \\
\hline Non-white & 12 & 6 & \\
\hline White & 88 & 94 & \\
\hline BMI $\left(\mathrm{kg} / \mathrm{m}^{2}\right)$ & 29 (SD 8) & 28 (SD 6) & 0.22 \\
\hline SES & & & 0.09 \\
\hline Low & 26 & 25 & \\
\hline Moderate & 39 & 41 & \\
\hline High & 36 & 33 & \\
\hline Patient type (\%) & & & 0.21 \\
\hline Emergent & 16 & 10 & \\
\hline Non-emergent & 84 & 90 & \\
\hline APACHE ॥ & 17 (SD 9) & 15 (SD 7) & 0.03 \\
\hline Hospital LOS (days) & 9 (IQR 6-15) & 9 (IQR 6-12) & 0.32 \\
\hline $\begin{array}{l}\text { Vitamin D supplementa- } \\
\text { tion (\%) }\end{array}$ & & & $<0.01$ \\
\hline$<1000$ IU/day & 88 & 72 & \\
\hline$\geq 1000$ to $<4000 \mathrm{IU} /$ day & 12 & 28 & \\
\hline $25 \mathrm{OHD}(\mathrm{ng} / \mathrm{mL})$ & 14 (SD 4) & 27 (SD 7) & $<0.001$ \\
\hline In-hospital mortality (\%) & & & 0.03 \\
\hline Alive & 80 & 91 & \\
\hline Deceased & 20 & 9 & \\
\hline Discharge destination (\%) & & & $<0.01$ \\
\hline Non-home & 48 & 29 & \\
\hline Home & 52 & 71 & \\
\hline
\end{tabular}

$B M /$ body mass index, $S E S$ socioeconomic status, $A P A C H E / /$ acute physiology and chronic health evaluation II, LOS length of stay, 25OHD 25-hydroxyvitamin D

Data presented as either mean with standard deviation (SD), median with interquartile range (IQR), or proportions and compared using $t$ tests, MannWhitney tests, and Chi-squared tests, respectively. Significant $P$ values $(<0.05)$ are shown in italic. To convert $\mathrm{ng} / \mathrm{mL}$ to $\mathrm{nmol} / \mathrm{L}$, please multiply by 2.496

plausible covariates, demonstrated an inverse association between admission plasma 25OHD levels and nonhome discharge destination (OR per $1 \mathrm{ng} / \mathrm{mL}, 0.88 ; 95 \%$ CI 0.82-0.95). When vitamin D status was considered as a dichotomous variable, patients with $25 \mathrm{OHD}<20 \mathrm{ng} /$ $\mathrm{mL}$ were more than 2.5 times more likely to have a nonhome discharge destination compared to patients with $25 \mathrm{OHD} \geq 20 \mathrm{ng} / \mathrm{mL}$ (OR, 2.74; 95 \% CI 1.23-6.14). Additional variables found to be independently associated with non-home discharge destination in these models were APACHE II score, hospital LOS, and vitamin D supplementation.

\section{Discussion}

In this retrospective cohort study, we investigated whether vitamin D status determined at initiation of critical care was associated with subsequent discharge destination from the hospital. We demonstrated that plasma 25OHD levels measured on admission to the surgical ICU were inversely associated with the risk of a non-home discharge destination (i.e., patients with low 25OHD levels are more likely to have a non-home discharge destination). This relationship was most prominent when comparing patients with 25OHD levels $<20 \mathrm{ng} / \mathrm{mL}$ to those with levels $\geq 20 \mathrm{ng} / \mathrm{mL}$. However, due to the observational nature of this study, a causal inference about the effect of vitamin $\mathrm{D}$ status on discharge destination in critically ill surgical patients is limited. And while the association between vitamin D status and various provider-centered outcomes, such as hospital LOS and readmission rates, has previously been reported [22-24], its impact on a patient-centered outcome, such as discharge destination after hospitalization, has not been well explored. Nonetheless, the biologic plausibility of the relationship between vitamin D status and discharge destination is undeniable.

The wide-ranging role of vitamin D in musculoskeletal health, epithelial barrier site integrity, and regulation of both innate as well as adaptive immunity, in addition to calcium homeostasis, may explain how optimizing $25 \mathrm{OHD}$ levels in critically ill patients may improve outcomes [40]. Proximal muscle group weakness and atrophy, particularly of type II fibers, are associated with low vitamin D status [41-43], and profound deconditioning associated with muscle wasting in the ICU is associated with long-term physical as well as functional disability [44-46]. Vitamin D metabolites have been shown to affect muscle metabolism through a variety of pathways [43]. Most importantly, the vitamin D membrane receptor (VDR), which binds the most biologically active vitamin D metabolite 1,25-dihydroxyvitamin D (1,25OHD), is expressed in human skeletal muscle cells $[47,48]$. Modulated both by genetic transcription after transportation to the nucleus [49], and by direct interaction with muscle cell membranes resulting in second-messenger pathways [50], the 1,25OHD-VDR interaction results in increased calcium uptake within muscle cells [51].

Additionally, vitamin D has been shown to be important for the maintenance of epithelial and mucosal cells, in particular preserving the barrier functions of these cells [52]. Activity of the 1- $\alpha$-hydroxylase that converts 25OHD-1,25OHD has been demonstrated in epithelial cells of the respiratory system [53], intestine [54, 55], skin $[56,57]$, and endothelium [58]. Vitamin D supplementation has been shown to increase the growth and differentiation of respiratory epithelial cells [59], while low 


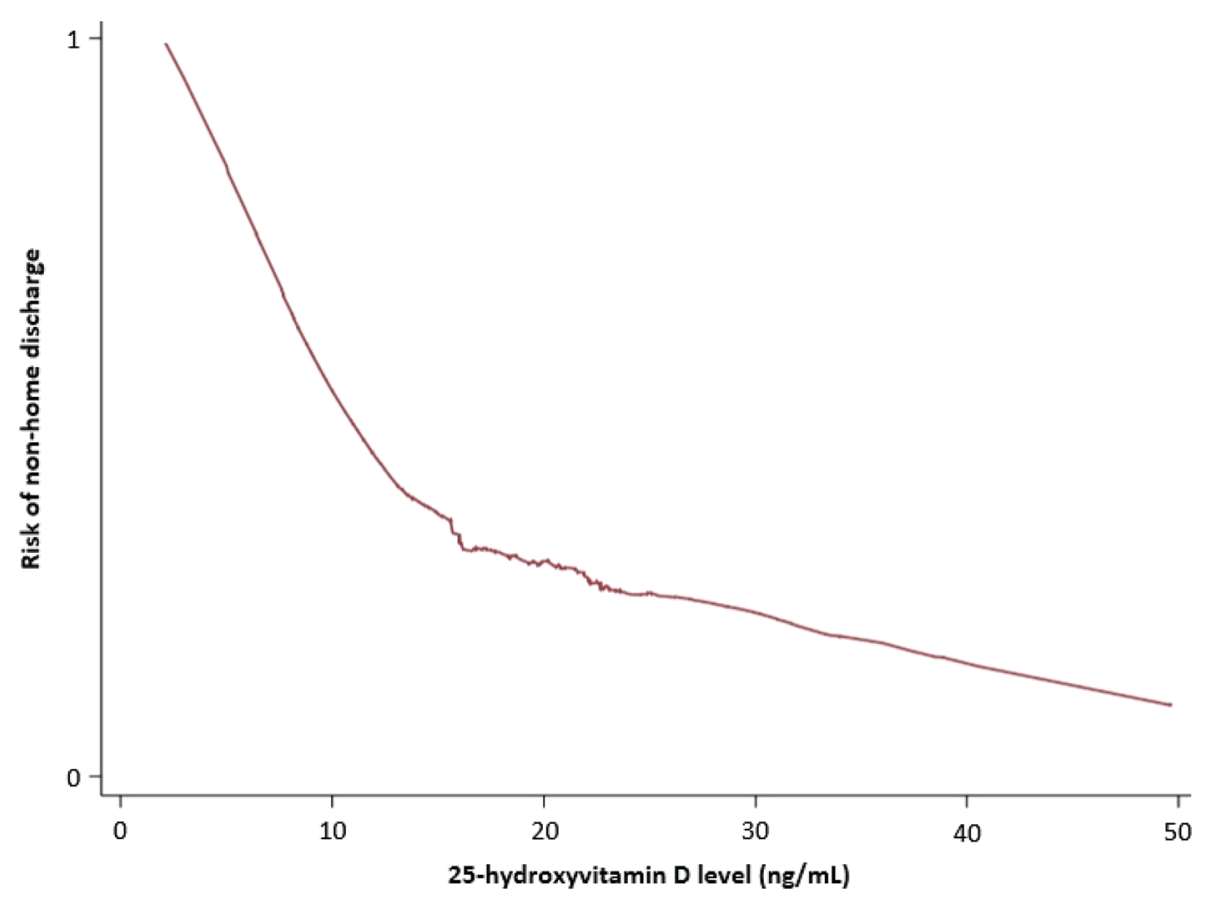

Fig. 1 LOWESS curve analysis demonstrates the relationship between vitamin D status and the risk of non-home discharge destination for 25OHD levels of $0-50 \mathrm{ng} / \mathrm{mL}$

vitamin D status has been shown to cause pulmonary epithelial dysfunction in mice [60]. Vitamin D metabolites have also been shown to promote colonic epithelial barrier integrity and function through the preservation of intercellular tight junctions in both in vitro and murine studies [61, 62], with low vitamin D status increasing the risk of colitis in animal models [62]. Furthermore, keratinocytes not only produce and metabolize the vitamin D precursor [63], but keratinocyte differentiation is in turn modulated by vitamin $\mathrm{D}$ and is essential for maintaining healthy skin $[64,65]$. And finally, in vitro studies have shown that in endothelium, supplementing with vitamin $\mathrm{D}$ reduces the generation of anion superoxides, prevents free radical release [66], and promotes endothelial cell viability through the production of nitric oxide $[66,67]$. Therefore, compromised natural barriers in the setting of low vitamin D status likely increases susceptibility to nosocomial infections, including central lineassociated blood stream infections, hospital-acquired pneumonia, and Clostridium difficile infections [40, 68, 69], which all not only increase the risk of mortality, but also lead to prolonged hospitalization and likely compound the functional decline associated with critical illness.

VDR is also expressed in cells of the innate and adaptive immune system [70], including $\mathrm{T}$ cells, activated B cells, and dendritic cells [71-75]. Low vitamin D status is linked to the Toll-like receptor stimulation of macrophages that leads to increased expression of VDR [76], assists with conversion of 25OHD-1,25OHD [77], and also upregulates the expression of endogenous antimicrobial peptides, cathelicidin (LL-37) and $\beta$-defensin $[20,76,78]$. These peptides have known activity against Gram-positive and Gram-negative bacteria, mycobacteria, viruses, and fungi [79], thereby suggesting an important role of optimal vitamin D status in prevention and potentially treatment of serious infections [80]. Indeed, recent evidence suggests that high-dose cholecalciferol (vitamin D3) supplementation in patients with severe sepsis or septic shock increases systemic cathelicidin levels, while modulating immunoregulatory cytokines such as interleukin (IL)-1 $\beta$ and IL-6 [31]. Previous studies have also suggested that vitamin $D$ is a key regulator of inflammatory cytokines [81-83].

While our findings are intriguing, it is important to discuss the limitations of our study. We performed a retrospective, observational analysis, and therefore, causality cannot be inferred. And despite our efforts to adjust for multiple covariates, the presence of residual confounding that may have contributed to the observed outcomes cannot be ruled out. Indeed, we are unable to fully adjust for baseline functional status, exposure to sunlight, as well as nutritional status before and through hospitalization. Additionally, hospital LOS is often influenced by several 
Table 2 Biologically plausible models to test the association of admission 25-hydroxyvitamin D level with non-home discharge destination in surgical intensive care unit patients $(n=300)$

\begin{tabular}{|c|c|c|}
\hline Covariate & $\begin{array}{l}\text { OR (95 \% Cl) } \\
250 H D \text { (continuous variable) }\end{array}$ & $\begin{array}{l}\text { OR }(95 \% \mathrm{Cl}) \\
25 \mathrm{OHD}(<20 \text { vs. } \geq 20 \mathrm{ng} / \mathrm{mL})\end{array}$ \\
\hline Age (years) & $1.01(0.98-1.04)$ & $1.00(0.98-1.03)$ \\
\hline \multicolumn{3}{|l|}{ Sex } \\
\hline Female & - & - \\
\hline Male & $0.81(0.36-1.83)$ & $1.08(0.51-2.31)$ \\
\hline \multicolumn{3}{|l|}{ Race } \\
\hline Non-white & - & - \\
\hline White & $1.57(0.96-2.56)$ & $2.12(0.52-8.68)$ \\
\hline $\mathrm{BMI}\left(\mathrm{kg} / \mathrm{m}^{2}\right)$ & $2.07(0.58-8.47)$ & $0.97(0.91-1.02)$ \\
\hline \multicolumn{3}{|l|}{ SES } \\
\hline Low & - & - \\
\hline Moderate & 1.09 (0.38-3.09) & $1.08(0.39-3.02)$ \\
\hline High & $1.07(0.36-3.18)$ & $0.92(0.32-2.65)$ \\
\hline \multicolumn{3}{|l|}{ Patient type } \\
\hline Emergent & - & - \\
\hline Non-emergent & $1.73(0.32-9.32)$ & $1.66(0.32-8.66)$ \\
\hline APACHE $\|$ & $1.33(1.22-1.45)$ & $1.32(1.22-1.43)$ \\
\hline Hospital LOS (days) & $1.18(1.11-1.25)$ & $1.18(1.11-1.25)$ \\
\hline \multicolumn{3}{|c|}{ Vitamin D supplementation (IU/day) } \\
\hline$<1000$ & - & - \\
\hline$\geq 1000$ to $<4000$ & $0.56(0.17-1.83)$ & $0.23(0.08-0.67)$ \\
\hline $250 H D(n g / m L)$ & $0.88(0.82-0.95)$ & $2.74(1.23-6.14)$ \\
\hline
\end{tabular}

(-) represents each referent variable

Statistically significant variables are highlighted in italic

OR odds ratio, $\mathrm{Cl}$ confidence interval, $B M I$ body mass index, SES socioeconomic status, APACHE II acute physiology and chronic health evaluation II, LOS length of stay, 25OHD 25-hydroxyvitamin D

factors, such as social and financial issues, that we could not fully adjust for in our model. Of note, we elected to use hospital LOS instead of ICU LOS, since patients may often remain in the ICU due to a lack of available beds on the general wards. Furthermore, discharge destination may be affected by financial and insurance considerations, the availability of home help, and family/social support-all factors that we are unable to adjust for in the present study. Moreover, we only recruited a limited number of patients from two surgical ICUs at a single, large referral center, which may decrease the generalizability of our results to all ICU patients. For the most part, patients recruited into the study were also racially homogenous, and this limited diversity may further affect the generalizability of our findings. In the present study, only $25 \mathrm{OHD}$ levels assessed within $24 \mathrm{~h}$ of ICU admission were considered; it is possible that this single data point does not reflect the variation in vitamin $\mathrm{D}$ status with inflammation, metabolic changes, fluid shifts, and systemic micro and macronutrient needs for the entire duration of critical illness $[22,84]$.
It is worth noting that more patients in our analytic cohort with admission 25OHD levels $\geq 20 \mathrm{ng} / \mathrm{mL}$ received vitamin $\mathrm{D}$ supplementation between $\geq 1000$ and $<4000 \mathrm{IU} /$ day during hospitalization, as compared to patients with levels $<20 \mathrm{ng} / \mathrm{mL}$ ( 28 vs. $12 \%$, respectively; $P<0.01$ ). This is due to the fact that patients with higher initial 25OHD levels were more likely to be taking vitamin D supplementation before hospitalization and as a result, it was more likely to be continued after ICU admission. Measurement of vitamin D status is not part of routine care in our surgical ICUs and all admission 25OHD levels were measured from frozen plasma samples several weeks after hospitalization (and therefore not temporally related to clinical decision-making). Since only $18 \%$ of the entire study cohort received vitamin D supplementation during hospitalization, we were likely underpowered to detect an independent association between supplementation status and discharge destination (the primary outcome) when the exposure of interest in our regression model (i.e., 25OHD) was considered as a continuous variable. Dichotomizing the exposure $(<20$ 
vs. $\geq 20 \mathrm{ng} / \mathrm{mL}$ ) improved the ability of our model to discriminate between patients who were and were not discharged home, and in doing so, there was likely sufficient power to also detect an independent association of supplementation status with discharge destination. Notable also, was the fact that the proportion of patients in each SES group did not differ by vitamin $\mathrm{D}$ status. This may be related to the generally high prevalence of low vitamin $D$ status in New England (due to geography and weather) and the enrollment of patients more likely to be indoors during the day (e.g., elderly, retirees, office workers). As such, these issues will need to be addressed in larger future studies to replicate and extend the results of our current study.

\section{Conclusion}

Our results suggest that vitamin D status may be a modifiable risk factor for discharge destination in surgical ICU patients. Given that suboptimal 25OHD levels are highly prevalent in ICU patients [25-29], further prospective studies are needed to validate our findings, to assess the potential benefits of optimizing 25OHD levels in critical illness, and to identify the mechanism by which vitamin D may impact patient-oriented outcomes in ICU patients.

\begin{abstract}
Abbreviations
LOS: length of stay; ICU: intensive care unit; 25OHD: 25-hydroxyvitamin D; LOWESS: locally weighted scatterplot smoothing; MGH: Massachusetts General Hospital; ELISA: enzyme-linked immunoabsorbent assay; BMI: body mass index; SES: socioeconomic status; APACHE II: acute physiology and chronic health evaluation; SD: standard deviation; IQR: interquartile range; OR: odds ratio; Cl: confidence interval; VDR: vitamin D membrane receptor; 1,25OHD: 1,25-dihydroxyvitamin D; IL: interleukin.
\end{abstract}

\section{Authors' contributions}

$\mathrm{KB}$ and $\mathrm{SAQ}$ jointly conceived the study and drafted the manuscript. CAC and $\mathrm{KBC}$ critically revised the manuscript. SAQ assembled the data and performed all statistical analyses. All authors read and approved the final manuscript.

\section{Author details \\ ' Department of Anesthesia, Critical Care, and Pain Medicine, Massachusetts General Hospital, Harvard Medical School, 55 Fruit Street, GRJ 402, Boston, MA 02114, USA. ${ }^{2}$ Department of Emergency Medicine, Massachusetts General Hospital, Boston, MA, USA. ${ }^{3}$ Department of Medicine, Harvard Medical School, Boston, MA, USA. ${ }^{4}$ Department of Epidemiology, Harvard School of Public Health, Boston, MA, USA. ${ }^{5}$ Department of Medicine, Brigham and Women's Hospital, Boston, MA, USA. ${ }^{6}$ Department of Anaesthesia, Harvard Medical School, Boston, MA, USA.}

\begin{abstract}
Acknowledgements
CAC received support from the United States National Institutes of Health grants R01 Al093723 and U01 Al087881. SAQ received support from the United States National Institutes of Health grants T32 GM007592, UL1 RR025758, and L30 TR001257 as well as from Harvard Medical School.
\end{abstract}

\section{Compliance with ethical guidelines}

\section{Competing interests}

The authors declare that they have no competing interests.
Received: 21 July 2015 Accepted: 28 August 2015

Published online: 17 September 2015

\section{References}

1. Kaukonen KM, Bailey M, Suzuki S, Pilcher D, Bellomo R. Mortality related to severe sepsis and septic shock among critically ill patients in Australia and New Zealand, 2000-2012. JAMA. 2014;311(13):1308-16.

2. Gaieski DF, Edwards JM, Kallan MJ, Carr BG. Benchmarking the incidence and mortality of severe sepsis in the United States. Crit Care Med. 2013;41(5):1167-74

3. Stevenson EK, Rubenstein AR, Radin GT, Wiener RS, Walkey AJ. Two decades of mortality trends among patients with severe sepsis: a comparative meta-analysis. Crit Care Med. 2014;42(3):625-31.

4. Klein MB, Goverman J, Hayden DL, Fagan SP, McDonald-Smith GP, et al. Benchmarking outcomes in the critically injured burn patient. Ann Surg. 2014;259(5):833-41.

5. Girard K, Raffin TA. The chronically critically ill: To save or let die? Respir Care. 1985;30(5):339-47.

6. Carson SS. Definitions and epidemiology of the chronically critically ill. Respir Care. 2012;57(6):848-56 (discussion 856-8).

7. Macintyre NR. Chronic critical illness: the growing challenge to health care. Respir Care. 2012;57(6):1021-7.

8. Nelson JE, Cox CE, Hope AA, Carson SS. Chronic critical illness. Am J Respir Crit Care Med. 2010;182(4):446-54

9. Donahoe MP. Current venues of care and related costs for the chronically critically ill. Respir Care. 2012;57(6):867-86 (discussion 886-8)

10. Shulman MA, Myles PS, Chan MTV, Mcllroy DR, Wallace S, Ponsford P. Measurement of disability-free survival after surgery. Anesthesiology. 2015;122(3):524-36

11. Bala M, Kashuk JL, Willner D, Kaluzhni D, Bdolah-Abram T, Almogy G. Looking beyond discharge: clinical variables at trauma admission predict long term survival in the older severely injured patient. World J Emerg Surg WJES. 2014;9:10. doi:10.1186/1749-7922-9-10.

12. Chen $\mathrm{C}$, Sia I, Ma H, et al. The synergistic effect of functional status and comorbidity burden on mortality: a 16-year survival analysis. Laks J (ed). PLoS One. 2014;9(8):e106248.

13. Fried TR, Bradley EH, Towle VR, Allore H. Understanding the treatment preferences of the seriously ill. N Engl J Med. 2002;346:1061-6.

14. Lane-Fall MB, Iwashyna TJ, Cooke CR, Benson NM, Kahn JM. Insurance and racial differences in long-term acute care utilization after critical illness. Crit Care Med. 2012;40(4):1143-9.

15. Rudberg MA, Sager MA, Zhang J. Risk factors for nursing home use after hospitalization for medical illness. J Gerontol A Biol Sci Med Sci. 1996;51:M189-94.

16. Rady MY, Johnson DJ. Hospital discharge to care facility. A patientcentered outcome for the evaluation of intensive care for octogenarians. Chest. 2004;126:1583-91.

17. Gehlbach BK, Salamanca VR, Levitt JE, et al. Patient factors associated with hospital discharge to care facility following critical illness. Am J Crit Care. 2011;20(5):378-86. doi:10.4037/ajcc2011827.

18. Szubski CR, Tellez A, Klika AK, et al. Predicting discharge to a long-term acute care hospital after admission to an intensive care unit. Am J Crit Care. 2014;23:e46-53.

19. DeLuca HF. Overview of general physiologic features and functions of vitamin D. Am J Clin Nutr. 2004;80(Suppl):1689S-96S.

20. Holick MF. Vitamin D deficiency. N Engl J Med. 2007;357(3):266-81.

21. Quraishi SA, Camargo CA Jr. Vitamin D in acute stress and critical illness. Curr Opin Clin Nutr Metab Care. 2012;15(6):625-34.

22. Quraishi SA, Bittner EA, Blum L, McCarthy CM, Bhan I, Camargo CA $J$ r. Prospective study of vitamin $D$ status at initiation of care in critically ill surgical patients and risk of 90-day mortality. Crit Care Med. 2014;42(6):1365-71.

23. Matthews LR, Ahmed Y, Wilson KL, Griggs DD, Danner OK. Worsening severity of vitamin $D$ deficiency is associated with increased length of stay, surgical intensive care unit cost, and mortality rate in surgical intensive care unit patients. Am J Surg. 2012;204:37-43. 
24. Amrein K, Schnedl C, Holl A, et al. Effect of high-dose vitamin D3 on hospital length of stay in critically ill patients with vitamin D deficiency: the VITdAL-ICU randomized clinical trial. JAMA. 2014;312(15):1520-30.

25. Nair P, Lee P, Reynolds C, Nguyen ND, Myburgh J, Eisman JA, Center JR. Significant perturbation of vitamin D-parathyroid-calcium axis and adverse clinical outcomes in critically ill patients. Intensive Care Med. 2013;39(2):267-74.

26. Venkatram S, Chilimuri S, Adrish M, Salako A, Patel M, Diaz-Fuentes G. Vitamin D deficiency is associated with mortality in the medical intensive care unit. Crit Care. 2011;15:R292.

27. Lucidarme O, Messai E, Mazzoni T, Arcade M, du Cheyron D. Incidence and risk factors of vitamin D deficiency in critically ill patients: results from a prospective observational study. Intensive Care Med. 2010;36:1609-11.

28. Flynn L, Zimmerman LH, McNorton K, et al. Effects of vitamin D deficiency in critically ill surgical patients. Am J Surg. 2012;203:379-82.

29. Lee P, Eisman JA, Center JR. Vitamin D deficiency in critically ill patients. N Engl J Med. 2009;360(18):1912-4. doi:10.1056/NEJMc0809996.

30. Amrein $\mathrm{K}$, Sourij $\mathrm{H}$, Wagner $\mathrm{G}$, et al. Short-term effects of high-dose oral vitamin D3 in critically ill vitamin D deficient patients: a randomized, double-blind, placebo-controlled pilot study. Crit Care. 2011;15(2):R104.

31. Quraishi SA, De Pascale G, Needleman JS, Nakazawa H, Kaneki M, Bajwa EK, Camargo CA Jr, Bhan I. Effect of cholecalciferol supplementation on vitamin d status and cathelicidin levels in sepsis: a randomized, PlaceboControlled Trial. Crit Care Med. 2015:43:1928-37.

32. Quraishi SA, McCarthy C, Blum L, Cobb JP, Camargo CA Jr. Plasma 25-Hydroxyvitamin D Levels at Initiation of Care and Duration of Mechanical Ventilation in Critically III Surgical Patients. JPEN J Parenter Enteral Nutr. 2015. doi:10.1177/0148607114566276.

33. U.S. Census Bureau. "SELECTED ECONOMIC CHARACTERISTICS 2009-2013 American Community Survey 5-Year Estimates".

34. Cleveland WS. Robust locally weighted regression and smoothing scatterplots. J Am Stat Assoc. 1979;74(368):829-36.

35. Cleveland WS, Devlin SJ. Locally weighted regression: an approach to regression analysis by local fitting. J Am Stat Assoc. 1988;83(403):596-610.

36. Ross AC, Manson JE, Abrams SA, Aloia JF, Brannon PM, Clinton SK, DurazoArvizu RA, Gallagher JC, Gallo RL, Jones G, Kovacs CS, Mayne ST, Rosen CJ, Shapses SA. The 2011 report on dietary reference intakes for calcium and vitamin D from the Institute of Medicine: what clinicians need to know. J Clin Endocrinol Metab. 2011;96(1):53-8.

37. Yeh DD, Fuentes E, Quraishi SA, Cropano C, Kaafarani H, Lee J, King DR, DeMoya M, Fagenholz P, Butler K, Chang Y, Velmahos G. Adequate nutrition may get you home: effect of caloric/protein deficits on the discharge destination of critically ill surgical patients. JPEN J Parenter Enteral Nutr. 2015. doi:10.1177/0148607115585142.

38. Gehlbach BK, Salamanca VR, Levitt JE, Sachs GA, Sweeney MK, PohIman AS, Charbeneau J, Krishnan JA, Hall JB. Patient-related factors associated with hospital discharge to a care facility after critical illness. Am J Crit Care. 2011;20(5):378-86. doi:10.4037/ajcc2011827.

39. Wunsch $H$, Guerra $C$, Barnato $A E$, Angus DC, Li G, Linde-Zwirble WT. Three-year outcomes for Medicare beneficiaries who survive intensive care. JAMA. 2010;303(9):849-56.

40. Lee P, Nair P, Eisman JA, Center JR. Vitamin D deficiency in the intensive care unit: an invisible accomplice to morbidity and mortality? Intensive Care Med. 2009;35(12):2028-32. doi:10.1007/s00134-009-1642-x (Epub 2009 Sep 15).

41. Janssen HC, Samson MM, Verhaar HJ. Vitamin D deficiency, muscle function, and falls in elderly people. Am J Clin Nutr. 2002;75(4):611-5.

42. Ceglia L, Niramitmahapanya S, da Silva Morais M, Rivas DA, Harris SS, Bischoff-Ferrari $\mathrm{H}$, Fielding RA, Dawson-Hughes $\mathrm{B}$. A randomized study on the effect of vitamin $D_{3}$ supplementation on skeletal muscle morphology and vitamin D receptor concentration in older women. J Clin Endocrinol Metab. 2013;98(12):E1927-35.

43. Boland R. Role of vitamin D in skeletal muscle function. Endocr Rev. 1986;7:434-48

44. Connolly B, Salisbury L, O'Neill B, Geneen L, Douiri A, Grocott MP, Hart N, Walsh TS, Blackwood B, ERACIP Group. Exercise rehabilitation following intensive care unit discharge for recover from critical illness. Cochrane Database Syst Rev. 2015;6:CD008632 (Epub ahead of print).

45. Needham DM, Davidson J, Cohen H, Hopkins RO, Weinert C, Wunsch H, Zawistowski C, Bemis-Dougherty A, Berney SC, Bienvenu OJ, Brady SL, Brodsky MB, Denehy L, Elliott D, Flatley C, Harabin AL, Jones C, Louis D,
Meltzer W, Muldoon SR, Palmer JB, Perme C, Robinson M, Schmidt DM, Scruth E, Spill GR, Storey CP, Render M, Votto J, Harvey MA. Improving long-term outcomes after discharge from intensive care unit: report from a stakeholders' conference. Crit Care Med. 2012;40(2):502-9. doi:10.1097/ cCM.0b013e318232da75.

46. Connolly B, MacBean V, Crowley C, Lunt A, Moxham J, Rafferty GF, Hart N. Ultrasound for the assessment of peripheral skeletal muscle architecture in critical illness: a systematic review. Crit Care Med. 2015;43(4):897-905. doi:10.1097/CCM.0000000000000821.

47. Bischoff HA, Borchers M, Gudat F, et al. In situ detection of 1,25-dihydroxyvitamin D3 receptor in human skeletal muscle tissue. Histochem J. 2001;33:19-24.

48. Costa EM, Blau HM, Feldman D. 1,25-Dihydroxyvitamin D3 receptors and hormonal responses in cloned human skeletal muscle cells. Endocrinology. 1986;119:2214-20.

49. Simpson RU, Thomas GA, Arnold AJ. Identification of 1,25-dihydroxyvitamin D3 receptors and activities in muscle. J Biol Chem. 1985:260:8882-91.

50. Nemere I, Schwartz Z, Pedrozo H, Sylvia VL, Dean DD, Boyan BD. Identification of a membrane receptor for 1,25-dihydroxyvitamin D3 which mediates rapid activation of protein kinase C. J Bone Miner Res. 1998;13:1353-9.

51. Vazquez G, de Boland AR, Boland R. Stimulation of $\mathrm{Ca}^{2+}$ release-activated $\mathrm{Ca}^{2+}$ channels as a potential mechanism involved in non-genomic 1,25(OH)2-vitamin $\mathrm{D}_{3}$-induced $\mathrm{Ca}^{2+}$ entry in skeletal muscle cells. Biochem Biophys Res Commun. 1997;239:562-5.

52. Zhang YG, Wu S, Sun J. Vitamin D, vitamin D receptor, and tissue barriers. Tissue Barriers. 2013;1(1) (pii: e23118)

53. Hansdottir S, Monick MM, Hinde SL, Lovan N, Look DC, Hunninghake GW. Respiratory epithelial cells convert inactive vitamin D to its active form: potential effects on host defense. J Immunol. 2008;181:7090-9.

54. Tangpricha V, Flanagan JN, Whitlatch LW, Tseng CC, Chen TC, Holt PR, Lipkin MS, Holick MF. 25-Hydroxyvitamin D-1-hydroxylase in normal and malignant colon tissue. Lancet. 2001;357:1673-4.

55. Ogunkolade BW, Boucher BJ, Fairclough PD, Hitman GA, Dorudi S, Jenkins PJ, Bustin SA. Expression of 25-hydroxyvitamin D-1-hydroxylase mRNA in individuals with colorectal cancer. Lancet. 2002;359:1831-2.

56. Bikle DD, Nemanic MK, Gee E, Elias P. 1,25-Dihydroxyvitamin D3 production by human keratinocytes: kinetics and regulation. J Clin Invest. 1986;78:557-66.

57. Schauber J, Dorschner RA, Coda AB, Buchau AS, Liu PT, Kiken D, Helfrich YR, Kang S, Elalieh HZ, Steinmeyer A, et al. Injury enhances TLR2 function and antimicrobial peptide expression through a vitamin D-dependent mechanism. J Clin Invest. 2007;117:803-11.

58. Zehnder D, Bland R, Chana RS, Wheeler DC, Howie AJ, Williams MC, Stewart PM, Hewison M. Synthesis of 1,25-dihydroxyvitamin D(3) by human endothelial cells is regulated by inflammatory cytokines: a novel autocrine determinant of vascular cell adhesion. J Am Soc Nephrol. 2002;13(3):621-9.

59. Brockman-Schneider RA, Pickles RJ, Gern JE. Effects of vitamin D on airway epithelial cell morphology and rhinovirus replication. PLoS One. 2014;9(1):e86755. doi:10.1371/journal.pone.0086755 (eCollection 2014).

60. Zosky GR, Berry LJ, Elliot JG, James AL, Gorman S, et al. Vitamin d deficiency causes deficits in lung function and alters lung structure. Am J Respir Crit Care Med. 2011;183:1336-43.

61. Zhao $\mathrm{H}$, Zhang $\mathrm{H}$, Wu H, et al. Protective role of 1,25(OH)2 vitamin D3 in the mucosal injury and epithelial barrier disruption in DSS-induced acute colitis in mice. BMC Gastroenterol. 2012;12:57.

62. Assa A, Vong L, Pinnell LJ, Avitzur N, Johnson-Henry KC, Sherman PM. Vitamin $D$ deficiency promotes epithelial barrier dysfunction and intestinal inflammation. J Infect Dis. 2014;210(8):1296-305. doi:10.1093/infdis/ jiu235 (Epub 2014 Apr 21)

63. Bikle DD, Nemanic MK, Gee E, Elias P. 1,25- Dihydroxyvitamin D3 production by human keratinocytes. Kinetics and regulation. J Clin Invest. 1986;78:557-66.

64. Bikle DD. Vitamin D regulated keratinocyte differentiation. J Cell Biochem. 2004;92(3):436-44.

65. Bikle DD, Chang S, Crumrine D, et al. 25 hydroxyvitamin D 1 [alpha]hydroxylase is required for optimal epidermal differentiation and permeability barrier homeostasis. J Invest Dermatol. 2004;122:984-92.

66. Uberti F, Lattuada D, Morsanuto V, Nava U, Bolis G, Vacca G, Squarzanti DF, Cisari C, Molinari C. Vitamin D protects human endothelial cells from 
oxidative stress through the autophagic and survival pathways. J Clin Endocrinol Metab. 2014;99(4):1367-74. doi:10.1210/jc.2013-2103 (Epub 2013 Nov 27)

67. Molinari C, Uberti F, Grossini E, Vacca G, Carda S, Invernizzi M, Cisari C. 1 $\alpha, 25$-dihydroxycholecalciferol induces nitric oxide production in cultured endothelial cells. Cell Physiol Biochem. 2011;27(6):661-8. doi:10.1159/000330075 (Epub 2011 Jun 17).

68. Quraishi SA, Litonjua AA, Moromizato T, Gibbons FK, Camargo CA Jr, Giovannucci E, Christopher KB. Association between prehospital vitamin D status and hospital-acquired Clostridium difficile infections. JPEN J Parenter Enteral Nutr. 2015;39(1):47-55. doi:10.1177/0148607113511991 (Epub 2014 Feb 3).

69. Quraishi SA, Litonjua AA, Moromizato T, Gibbons FK, Camargo CA Jr, Giovannucci E, Christopher KB. Association between prehospital vitamin D status and hospital-acquired bloodstream infections. Am J Clin Nutr. 2013;98(4):952-9. doi:10.3945/ajcn.113.058909 (Epub 2013 Aug 14).

70. Adams JS, Hewison M. Unexpected actions of vitamin D: new perspectives on the regulation of innate and adaptive immunity. Nat Clin Pract Endocrinol Metab. 2008;4:80-90

71. Dickson I. New approaches to vitamin D. Nature. 1987;325:18.

72. Minghetti PP, Norman AW. 1,25(OH)2-vitamin D3 receptors: gene regulation and genetic circuitry. FASEB J. 1988;2:3043-53.

73. Mahon BD, Wittke A, Weaver V, Cantorna MT. The targets of vitamin D depend on the differentiation and activation status of CD4 positive T cells. J Cell Biochem. 2003;89:922-32.

74. Heine G, Anton K, Henz BM, Worm M. 1alpha,25-dihydroxyvitamin D3 inhibits anti-CD40 plus IL-4-mediated IgE production in vitro. Eur J Immunol. 2002;32:3395-404.

75. Adorini L, Penna G, Giarratana N, Roncari A, Amuchastegui S, Daniel KC, Uskokovic M. Dendritic cells as key targets for immunomodulation by vitamin D receptor ligands. J Steroid Biochem Mol Biol. 2004;89-90:437-41.
76. Liu PT, Stenger S, Li H, Wenzel L, Tan BH, Krutzik SR, Ochoa MT, Schauber J, Wu K, Meinken C, et al. Toll-like receptor triggering of a vitamin D-mediated human antimicrobial response. Science. 2006;311:1770-3.

77. Bhalla AK, Amento EP, Krane SM. Differential effects of 1,25-dihydroxyvitamin D3 on human lymphocytes and monocyte/macrophages: Inhibition of interleukin-2 and augmentation of interleukin-1 production. Cell Immunol. 1986;98:311-22.

78. Wang TT, Nestel FP, Bourdeau V, Nagai Y, Wang Q, Liao J, Tavera-Mendoza L, Lin R, Hanrahan JW, Mader S, White JH. Cutting edge: 1,25-dihydroxyvitamin D3 is a direct inducer of antimicrobial peptide gene expression. J Immunol. 2004;173(5):2909-12.

79. Durr UH, Sudheendra US, Ramamoorthy A. LL-37, the only human member of the cathelicidin family of antimicrobial peptides. Biochim Biophys Acta. 2006;1758:1408-25.

80. Jeng L, Yamshchikov AV, Judd SE, Blumberg HM, Martin GS, Ziegler TR, Tangpricha $V$. Alterations in vitamin D status and anti-microbial peptide levels in patients in the intensive care unit with sepsis. J Transl Med. 2009;23:28.

81. Baeke F, Takiishi T, Korf H, Gysemans C, Mathieu C. Vitamin D: modulator of the immune system. Curr Opin Pharmacol. 2010;10(4):482-96. doi:10.1016/j.coph.2010.04.001 (Epub 2010 Apr 27).

82. Baeke F, Gysemans C, Korf H, Mathieu C. Vitamin D insufficiency: implications for the immune system. Pediatr Nephrol. 2010;25(9):1597-606. doi:10.1007/s00467-010-1452-y (Epub 2010 Feb 24)

83. Hewison M. Vitamin D and the immune system: new perspectives on an old theme. Endocrinol Metab Clin North Am. 2010;39(2):365-79. doi:10.1016/j.ecl.2010.02.010 (table of contents).

84. Krishnan A, Venkatesh B. Vitamin D measurement in the intensive care unit: methodology, clinical relevance and interpretation of a random value. Inflamm Allergy Drug Targets. 2013;12(4):230-8.

\section{Submit your manuscript to a SpringerOpen ${ }^{\circ}$ journal and benefit from:}

- Convenient online submission

- Rigorous peer review

- Immediate publication on acceptance

- Open access: articles freely available online

- High visibility within the field

- Retaining the copyright to your article

Submit your next manuscript at $>$ springeropen.com 